\title{
Compound urban crises
}

\author{
Linda Westman (1), James Patterson, Rachel Macrorie, \\ Christopher J. Orr, Catherine M. Ashcraft, Vanesa Castán Broto, \\ Dana Dolan, Mukesh Gupta, Jeroen van der Heijden, Thomas Hickmann, \\ Robert Hobbins, Marielle Papin, Enora Robin, Christina Rosan, \\ Jonas Torrens, Robert Webb
}

Received: 7 April 2021/Revised: 3 November 2021/Accepted: 22 December 2021/Published online: 14 February 2022

\begin{abstract}
The crises that cities face-such as climate change, pandemics, economic downturn, and racism-are tightly interlinked and cannot be addressed in isolation. This paper addresses compound urban crises as a unique type of problem, in which discrete solutions that tackle each crisis independently are insufficient. Few scholarly debates address compound urban crises and there is, to date, a lack of interdisciplinary insights to inform urban governance responses. Combining ideas from complex adaptive systems and critical urban studies, we develop a set of boundary concepts (unsettlement, unevenness, and unbounding) to understand the complexities of compound urban crises from an interdisciplinary perspective. We employ these concepts to set a research agenda on compound urban crises, highlighting multiple interconnections between urban politics and global dynamics. We conclude by suggesting how these entry points provide a theoretical anchor to develop practical insights to inform and reform urban governance.
\end{abstract}

Keywords Cities - Complex adaptive systems · Compound urban crises - Critical urban studies . Governance

\section{INTRODUCTION}

From economic downturn and austerity to inequalities and racism, pandemics, rapid technological shifts, ecological crises, and political polarisation, challenges to sustainability are not only numerous but increasingly interactive. Addressing any of these crises in isolation is impossible. For example, the climate emergency and social equity crises are tightly interlinked (Long and Rice 2020). In addition, turbulence is becoming an ever more pervasive global phenomenon (Dauvergne and Shipton forthcoming), creating a renewed scholarly interest in crises, disasters, and emergencies in the context of sustainability politics (Patterson et al. 2021).

In this paper, we focus on cities as sites where multiple crises manifest. Urban areas have long been viewed as recipients of different forms of shocks, ranging from violence (Muggah and Savage 2012) to pandemics (Keil and Ali 2007). Recent calls to address the climate crisis reverberate through urban politics and give it a renewed sense of urgency (Ruiz-Campillo et al. 2021). Protests against social, racial, gender-based, and economic injustice have erupted in cities across the globe, stressing enduring problems that have reached unbearable proportions (e.g. Sehnbruch and Donoso Knaudt 2020). Cities also face a global biodiversity crisis, forced migration, and economic shocks exacerbated by eroding labour protections, low-paid work, and poverty (Haase et al. 2018). City authorities are expected to respond to these issues, often despite limited formal powers and ability to raise funds, fragmented governance systems, and (in some parts of the world) longterm erosion of governance capacities due to funding cuts and privatisation.

Two significant challenges are understanding these interconnected issues and delivering appropriate and equitable responses. There are, however, gaps in the knowledge on the phenomenon of co-occurring urban crises. First, an established research tradition addresses the interplay between drivers and outcomes of crises, especially the scholarships on transboundary crises (Boin 2019) and compound risk (Zscheischler et al. 2018). However, these theories are not grounded explicitly in urban perspectives. Crises have shaped cities through history, reflecting entrenched social and economic inequality patterns and injustices. Contemporary disruptions are 
conditioned within particular urban contexts that shape their form, consequences, and possible responses. Understanding these dynamics requires analytical lenses attuned to political and spatial dimensions, often not reflected in traditional crisis or risk theory. Indeed, scholars of crisis call for more nuanced frameworks (Mitroff et al. 2004), particularly concerning social and historical contexts that shape disruption (Quarantelli et al. 2018).

Second, urban studies scholarship has long attended to how systemic vulnerabilities and inequalities shape the reproduction of everyday life in cities (e.g. Lees 2012; Pulido 2017). Yet, this body of research is seldom in dialogue with complex systems analyses. Today, the underlying causes of disruption in cities originate far beyond any given urban territory. They may relate to multiple levels of governance, ecosystem disruptions in other parts of the world, broad social struggles (e.g. over rights and recognition), and global economic forces (e.g. international finance). There is a need for analytical perspectives that consider both historical constituents of urban vulnerabilities and novel mechanisms of reproduction of risk based on global interconnectivity. Thus, the objective of this paper is to formulate a conceptual approach that facilitates the exchange of insights into compound urban crises across disciplinary boundaries.

The paper combines two strands of scholarship: complex adaptive systems (CAS) and critical urban studies (CUS). The CAS literature offers insight into the systemic nature of compound crises, while debates in CUS highlight asymmetric impacts on social groups across diverse settings. Despite their mutual interests, interchanges between these two bodies of work have been rare. Our analysis identifies entry points to examine convergences and complementarities between CAS and CUS. We think of these entry points as boundary concepts, that is, as anchors that facilitate interdisciplinary dialogue, shared vocabularies, and joint knowledge production. Boundary concepts are "words that operate as concepts in different disciplines or perspectives, refer to the same object, phenomenon, process or quality of these, but carry (sometimes very) different meanings in those different disciplines or perspectives" (Mollinga 2008, p. 25). Boundary concepts create bridges between literatures that address similar concerns, yet are not in dialogue. We deploy boundary concepts strategically to create a cognitive space where the contrasts between different systems of signification can be examined. The three boundary concepts for the study of compound urban crises that facilitate the interchange between CAS and CUS are unsettlement (enduring disruption of governance systems and everyday lives), unevenness (differentiated impacts across diverse societies), and unbounding (indeterminate problem boundaries and interactions).
The paper proceeds as follows. In 'Conceptualising compound urban crises', we map the theoretical foundation for compound urban crises and elaborate on the three boundary concepts. In the following section, 'A research agenda for the study of compound urban crises', we outline a research agenda indicated by these boundary concepts, highlighting the interconnections between global dynamics and the politics of urban precarity, the reproduction of structural injustice in cities, and the challenge of achieving knowledge pluralism. Finally, we reflect on the prospects of boundary concepts to stimulate exchange across scholarly divides.

\section{CONCEPTUALISING COMPOUND URBAN CRISES}

\section{From single to compound crises}

A crisis involves uncertainty, urgency, and threats to fundamental social structures or values (Farazmand 2001; Boin et al. 2016). In this paper, we understand urban crises as "a continuum where chronic vulnerabilities or structural states of crisis can themselves lead to episodic moments of acute shocks" (Robin et al. 2019), which destabilise operations and require urgent responses.

In the context of disruption in cities, treating crises as single processes or events is becoming increasingly untenable. Many contemporary urban crises cannot be untied from one another, and assigning causes, impacts, and responses is not a clear-cut task (Katz 2010). There is disagreement about relevant timeframes, spatial scales, and affected social groups. Figure 1 illustrates two different ways of viewing crises from a temporal perspective, as either singular or compound crises. For example, climate change is a phenomenon that develops over the longue durée (though manifesting through immediate disasters), which over time has accumulated to threaten global earth system functions. By contrast, the COVID-19 pandemic emerged as a sudden acute moment of shock (Fig. 1A). Crises of finance and migration commonly face cities and may be sporadic or chronic. A perspective of compound crises emphasises interconnections between these issues, overlapping and varying over time, creating bundles of interlinked challenges. Compound crises lack self-evident stopping rules for delineating the scope of attention; the interaction between issues cannot be ignored (Fig. 1B).

Crises are socially constructed phenomena ('t Hart 1993; Quarantelli et al. 2018), caused by multiple exogenous and endogenous factors (Pearson and Mitroff 1993). They seldom if ever occur singly, but instead in tandem or sequentially (Roux-Dufort 2009). There is often a complex interplay between fast- and slow-moving variables, such as in 'creeping crises' (Boin et al. 2020). In particular, the 
A
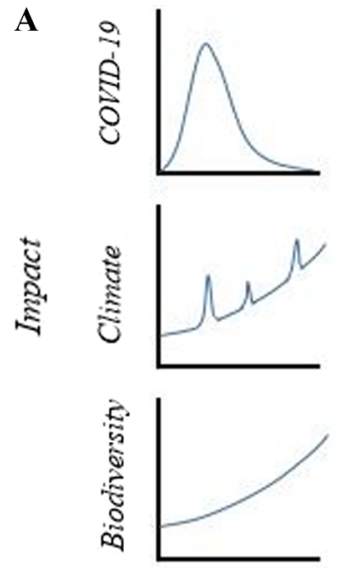

$t$
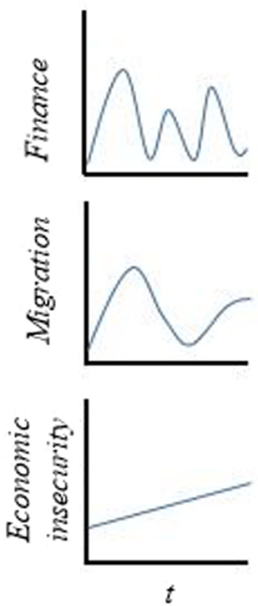

B

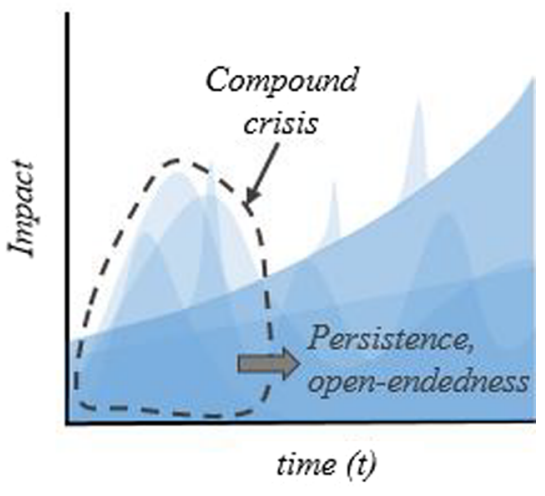

(among others)

Fig. 1 Multiple crises facing cities, viewed as either $\mathbf{A}$ singular crises, or $\mathbf{B}$ compound crises based on differences in temporal dynamics

concept of transboundary crises captures complex interactions of both causes and impacts ('t Hart et al. 2001; Ansell et al. 2010; Quarantelli et al. 2018; Boin 2019). Transboundary crises cross national boundaries and policy domains, incubate before rapidly escalating, may lack a clear beginning and end, defy efforts to identify causes, consequences, and trajectories, involve multiple actors with competing goals, and lack readily apparent solutions (Ansell et al. 2010; Quarantelli et al. 2018; Boin 2019).

Likewise, the concepts of compound and cascading risk capture the interaction of drivers (in multiple sectors), across multiple timeframes (fast- and slow-moving) and geographies (proximate and remote), which creates complex, non-linear, and unpredictable dynamics (Wahl et al. 2015; Zscheischler et al. 2018). The concept of compound risk, applied in climate change research, is interpreted by the Intergovernmental Panel on Climate Change as the spatial convergence of impacts in different sectors, which leads to extreme or high-risk consequences (Oppenheimer et al. 2014, p. 1057). Table 1 contrasts notions of singular crises, transboundary crises, and compound risks based on their temporal, spatial, and sectoral dimensions.

In conceptualising compound urban crises, we recognise that causes and impacts cut across temporal, spatial, and sectoral bounds. In contrast with the literature on transboundary crises, we locate the challenge of compound urban crises beyond the bounds and logics of the state. While the concept of transboundary crises was introduced to capture problems that escape institutional borders, the analysis departs from the limits (and opportunities) of central government institutions (Ansell et al. 2010; Boin 2019) or the global character of crises (Quarantelli et al. 2018). We argue that disruption in urban areas represents a more confounding challenge that always involves multiple levels of authority and spaces beyond the reach of formal institutions (e.g. informal settlements). We contend that, unlike compound risk, a focus on compound crises brings us closer to how people experience disruption as events in their everyday lives. The 'everydayness' of crises in urban areas is a pervasive phenomenon (Kaika 2012; Bhattacharyya 2015). The focus on events also directly motivates thinking on implications for urban governance, as crisis events call for urgent responses.

\section{The interdisciplinary foundation of compound urban crises}

Drawing on the insights of interconnectivity and non-linearity proposed by the compound risk literature, we argue that CAS theory can help understand compound urban crises. CAS theory was established within ecosystems studies and has gained prominence in social-ecological systems (SES) research and resilience studies (for an extensive review, see among others Lansing 2003; Levin et al. 2013; Preiser et al. 2018)). CAS theory emphasises a view of open systems comprising multiple interconnected elements across scales (Turner and Baker 2019; Orsini et al. 2020). Such systems change through adaptive cycles, which involve phases of continuity when rules are maintained, moments of abrupt crisis, and reorganisation (Walker et al. 2020). In essence, CAS adds the notion of adaptive capacities to traditional systems theory. CAS theory recognises that systems evolve in response to changes in their context, and that system constituents 'remember' and learn from previous configurations. Therefore, past changes influence the trajectory of future system change (Preiser et al. 2018). The idea that systems are potentially 'manageable' or 'controllable' in part explains 
Table 1 Causes and impacts in studies with a framing of singular crisis (with examples from Covid-19), transboundary crises, and compound risks (drawing on the climate change literature)

\begin{tabular}{|c|c|c|c|}
\hline Framing & Temporal & Spatial & Sectoral \\
\hline Singular crisis & $\begin{array}{l}\text { Crisis onset as a sudden moment when } \\
\text { causes are recognised and impacts } \\
\text { become salient (Buchheim et al. 2020) }\end{array}$ & $\begin{array}{l}\text { A single root cause is assumed ( } \mathrm{Li} \text { et al. } \\
\text { 2020) that produces impacts in specific } \\
\text { locales (Kim and Bostwick 2020) }\end{array}$ & $\begin{array}{l}\text { Causes and impacts are framed within } \\
\text { discrete sectors, such as health } \\
\text { (Sohrabi et al. 2020) or housing (AI- } \\
\text { Dafar 2020) }\end{array}$ \\
\hline $\begin{array}{l}\text { Transboundary } \\
\text { crisis }\end{array}$ & $\begin{array}{l}\text { The causes and impacts may be } \\
\text { indeterminate (no clear beginning and } \\
\text { end) (Ansell et al. 2010) }\end{array}$ & $\begin{array}{l}\text { There is no 'ground zero' (Boin 2019) or } \\
\text { 'point of origin' (Quarantelli et al. } \\
\text { 2018) in terms of cause, while impacts } \\
\text { transcend geographical, political, and } \\
\text { legal boundaries (Boin 2019) }\end{array}$ & $\begin{array}{l}\text { Causes and impacts manifest in } \\
\text { different sectors/policy domains, } \\
\text { involving multiple actors and } \\
\text { conflicting responsibilities (Boin } \\
\text { 2019) }\end{array}$ \\
\hline $\begin{array}{l}\text { Compound } \\
\text { risks }\end{array}$ & $\begin{array}{l}\text { Compound risks involve multiple causes } \\
\text { (Wahl et al. 2015; Zscheischler et al. } \\
\text { 2018). Impacts unfold on multiple } \\
\text { temporal scales (Zscheischler et al. } \\
\text { 2018) }\end{array}$ & $\begin{array}{l}\text { Compound risks arise from the interaction } \\
\text { of multiple causes at different spatial } \\
\text { scales or governance levels and } \\
\text { generate impacts across spatial scales } \\
\text { (Zscheischler et al. 2018) }\end{array}$ & $\begin{array}{l}\text { Compound risks arise from causes that } \\
\text { cut across sectoral boundaries and } \\
\text { impacts multiple sectors } \\
\text { (Oppenheimer et al. 2014) }\end{array}$ \\
\hline
\end{tabular}

the interest in CAS from SES scholars (Walker et al. 2004; Levin et al. 2013).

A strand of the CAS scholarship that engages explicitly with disruption is the literature on resilience. The concept of resilience has diverse intellectual origins and is conceptualised in a plurality of ways in theory and practice (Muñoz-Erickson et al. 2021). In the SES literature, resilience is defined as the "capacity of a system to absorb disturbance and reorganize while undergoing change so as to still retain essentially the same function" (Folke et al. 2010). The SES scholarship associates certain system attributes with high levels of resilience, such as diversity, opportunities for collaboration and social learning, selforganisation, reflexivity, and interaction across scales (Olsson et al. 2004; Lebel et al. 2006). This literature also explains that crises provide opportunities for social and institutional renewal and innovation (Walker et al. 2020). This notion is captured by the concept of transformation, which explains reconfiguration of essential system functions in response to ecological or social conditions that have become untenable (Walker et al. 2004).

Resilience theory has moved beyond academic debates to function as a framework and discourse that shapes policy and action in cities. As a concept that engages with multiple forms of risk, resilience can inspire interventions that strengthen social protection, disaster risk management, and ecosystems in cities (Ziervogel et al. 2017; Borie et al. 2019; Khirfan and El-Shayeb 2020). In collaborative and community-driven resilience projects, such interventions can be aligned with local priorities and open new spaces of experimentation, knowledge exchange, and social learning (Orleans Reed et al. 2013; Bahadur and Tanner 2014; Fastenrath and Coenen 2021). For example, the 100 Resilient Cities initiative, spearheaded by the Rockefeller
Foundation, has created a variety of technical tools, including a preliminary resilience assessment and agendasetting workshops, aimed to facilitate the development and adoption of resilience strategies in its member cities (Nielsen and Papin 2021). However, the mobilisation of resilience discourse in urban policy can also serve as a superficial branding exercise (Dolan et al. 2010; Van der Heijden 2017), which fails to address structural drivers of vulnerability. In particular, urban resilience programs often struggle to shift political-economic structures that generate marginality and exclusion in cities (Friend and Moench 2013; Chu and Michael 2019; Weinstein et al. 2019). For example, a recent review of the 100 Resilient Cities program found that plans generally neglect procedural and recognitional dimensions of equity, even though these aspects are essential to address underlying structural drivers of vulnerability, such as systemic racism (Meerow et al. 2019).

Similarly, there are concerns that some forms of CAS analysis overlook the situated nature of human-environment relations (Cote and Nightingale 2012; Olsson et al. 2015) and may not sufficiently address political dimensions, such as emerging concerns about resilience as a form of resistance (Rivero-Villar 2021). For example, the uncritical application of discourses of transformation in urban environments may yield limited change, or even reinforce dominant political-economic structures (Westman and Castán Broto 2021, Forthcoming). CAS theory provides only limited insight into urban politics, including questions of agency and normative perspectives on urban development (Berkes and Ross 2013; Nel et al. 2018). Hence, a dialogue with critical urban studies (CUS) can inform and expand the research interests in CAS. 
CUS raises issues that complement CAS theory. CUS does not offer a unified theoretical framework, but brings together different strands of work offering a critical perspective on how power relations, structural inequalities, cultural norms, forms of knowledge, values, and worldviews shape cities' political and social fabric, urban economies, urban infrastructures, and the built environment (Graham and Marvin 2002; Simone 2018; Castán Broto et al. 2020). CUS complements CAS by focussing on relations, processes of urban change, and their spatial manifestations. Within CUS, the city represents a "nexus of trans-local and post-human flows of people, investments, policies, and matter" (Lancione 2019, p. 183). This perspective invites us to think of the city as a processual and heterogeneous configuration of material elements (e.g. roads, dust, buildings, trains, rubbish), formal and informal institutions (e.g. laws, regulations, taxes), and beings (e.g. plants, animals, humans), all of which interact at multiple scales, producing variegated effects (McFarlane 2011). Like CAS, CUS recognises the open-ended nature of these interactions and the difficulty in predicting their outcomes. CUS research on population displacements and housing struggles (Lees 2012; Ghertner 2015; Anguelovski et al. 2019; Lancione 2020), environmental racism (Pulido 2017), and urban climate action (Bulkeley et al. 2014; Shi et al. 2016), to name only a few, provides insights into how enduring and episodic moments of crisis, as well as responses to those, unevenly impact urban dwellers.

\section{Boundary concepts for the study of compound urban crises}

We introduce three boundary concepts that can build dialogue across CAS and CUS: unsettlement, unevenness, and unbounding. Table 2 summarises our conceptualisation of these boundary concepts, also captured by the exploratory heuristic in Fig. 2. Below, we explain how these boundary concepts highlight complementary insights from CAS and CUS into compound urban crises.

\section{Unsettlement}

The CAS literature highlights how unsettlement is associated with non-linear feedback dynamics inherent to complex systems that are self-organising (Meadows 2008). Non-linear feedback refers to conditions in which the size of inputs is disproportional to expected outputs (Turner and Baker 2019). Given the unpredictability and unintended consequences that non-linear feedback creates, interventions into any single domain may be inadequate to resolve the problems of a destabilised system. Unsettlement manifests in the entangled interactions between human and natural systems, illustrated, for example, by the impacts of climate change. Climate impacts disrupt everyday life in cities through extreme events (e.g. floods and landslides) and slow-moving stressors (e.g. water scarcity and population displacement) (Revi et al. 2014). These impacts ripple through supply chains and infrastructure networks in

Table 2 Boundary concept definitions and summary of complementary insights brought by CAS and CUS

\begin{tabular}{|c|c|c|c|}
\hline & Definition & CAS & CUS \\
\hline Unsettlement & $\begin{array}{l}\text { A state in which compound crises come to } \\
\text { "unsettle" governance processes and } \\
\text { everyday ways of life (Orr 2020). Such } \\
\text { destabilisation disrupts established } \\
\text { practices and systems of material and } \\
\text { social support }\end{array}$ & $\begin{array}{l}\text { CAS theory explains how unsettlement } \\
\text { arises from the interconnected nature of } \\
\text { complex systems, with destabilising } \\
\text { drivers and feedbacks that are difficult } \\
\text { to anticipate and control }\end{array}$ & $\begin{array}{l}\text { CUS recognises that structural political- } \\
\text { economic forces create a permanent } \\
\text { state of risk and instability in urban life } \\
\text { for millions of people worldwide } \\
\text { (Schilling et al. 2019) }\end{array}$ \\
\hline Unevenness & $\begin{array}{l}\text { The differentiation of experiences, } \\
\text { impacts, and responses of compound } \\
\text { urban crises across groups in diverse } \\
\text { societies. Both compound crises } \\
\text { themselves, as well as governance } \\
\text { responses, contribute to unevenness }\end{array}$ & $\begin{array}{l}\text { From a CAS perspective, unevenness } \\
\text { relates to the principle of path } \\
\text { dependency, which explains how } \\
\text { differentiation within a system arises } \\
\text { and persists over time }\end{array}$ & $\begin{array}{l}\text { CUS highlights multiple historical drivers } \\
\text { that produce and reproduce social } \\
\text { categories of difference }\end{array}$ \\
\hline Unbounding & $\begin{array}{l}\text { The indeterminate conceptual and } \\
\text { political scope of compound urban } \\
\text { crises, which do not have clear stopping } \\
\text { rules for delineating causes and effects } \\
\text { and involve unanticipated interactions }\end{array}$ & $\begin{array}{l}\text { The CAS literature highlights emergence } \\
\text { as a key property of complex adaptive } \\
\text { systems, which captures how the } \\
\text { interaction between different forms of } \\
\text { shocks creates entirely new and } \\
\text { unpredictable phenomena }\end{array}$ & $\begin{array}{l}\text { CUS emphasises that uncertainty is an } \\
\text { inherent condition of urban life, but } \\
\text { also that the framing of crises is a } \\
\text { matter of social construction and power } \\
\text { differentials }\end{array}$ \\
\hline
\end{tabular}




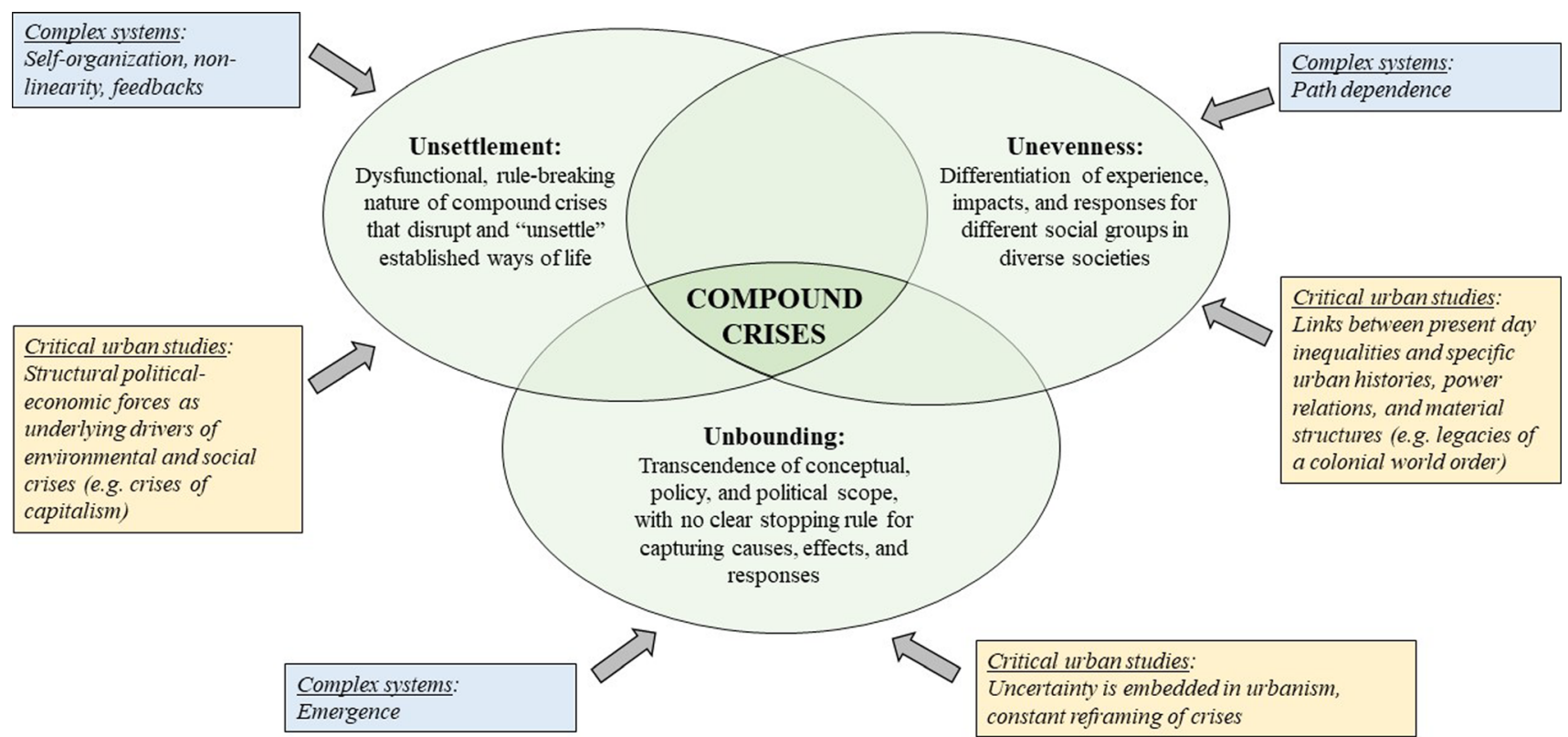

Fig. 2 Conceptualising urban governance challenges associated with compound urban crises according to three key boundary concepts (unsettlement, unevenness, unbounding), drawing on insights from CAS and CUT

interconnected global systems, linking risks in widely dispersed locations with unpredictable and unintended impacts in different parts of the world (Serre and Heinzlef 2018).

CUS highlights the role of structural political-economic forces (e.g. capitalism and neoliberal models of development) as underlying drivers of persistent environmental and social crises in cities, which produce risk as a permanent condition of everyday urban life (Molotch and Logan 1984). Any barrier to the continued circulation of capital within and between cities generates instability which drives recurring shocks (Harvey 2011). The global capitalist system also produces enduring dysfunction. Many millions of people in cities worldwide live under constant threat and lack of security linked to the slowmoving crisis of capitalism and the dominance of informal, temporary, and insecure forms of work in the global economy (Amin 2010). Approximately 60\% of the world's workforce is employed precariously, mostly women (ILO 2018). This everyday insecurity is acutely visible in patterns of poverty, exclusion, dispossession, housing insecurity, and violence in cities (Gay et al. 2013; Vilenica et al. 2020). Set against the urban modernist ideal of a politically unified, socially equitable, and infrastructurally cohesive city (Zeiderman et al. 2017), the concept of unsettlement shows that precarity is not an exception, but an essential dimension of the contemporary urban condition.

\section{BOX 1 EXAMPLE OF UNSETTLEMENT-COVID-19 AND AUSTERITY}

An example of unsettlement is the connection between crises of austerity and the COVID-19 pandemic. The UK austerity programme, introduced in response to the global financial crisis of 2007-8, led to a series of deep public spending cuts coupled with tax increases, resulting in a stalling in the rise of life expectancy for the first time in a century (Marmot 2020). Alongside, the growth of the so-called 'gig economy' saw a rise in zero-hour and fixed-term contracts (European Parliament 2016), increasing the number of households living in precarious conditions. When COVID-19 restrictions were introduced in March 2020, they interrupted established support systems and coping mechanisms and had unintended consequences that exacerbated insecurities. The crisis had disproportionate impacts on groups relying on low-paid and insecure work, such as caring, leisure, and other service occupations. With little security, this precariat faces threats of destitution, ill health, or possibly death (Butler 2020). 


\section{Unevenness}

According to CAS theory, system evolution is sensitive to initial conditions. The concept of path dependency explains how local rules develop within parts of a system, which shape dynamics as the system evolves (Levin 1998). While originally the concept described ecosystem dynamics, path dependencies also develop within institutional arrangements. The establishment of entrenched ways of thinking and doing, such as accepted management practices, can limit the ability to deal with crises. For example, path dependencies in public resource management institutions can hinder climate adaptation, contributing to the maintenance of social vulnerability (Barnett et al. 2015). In cities, path dependencies in institutions and spatial form can contribute to the cementation of inequalities over time, for example, through continued marginalisation of impoverished neighbourhoods (Wu et al. 2010). In the context of compound urban crises, the concept of path dependency explains patterns of vulnerability, as well as why reliance on established institutions may lead to unintended reproduction of inequalities.

CUS reveals links between present-day inequalities and specific urban histories, power relations, and material structures. For example, histories of colonisation, stigmatisation, and racial segregation have translated into patterns of economic and spatial inequalities in cities, including uneven access to services and decaying infrastructures (Njoh 2008; Picker 2017). Feminist and postcolonial perspectives highlight how urban space is structured according to histories and relations that reproduce white, heteronormative, and Eurocentric ideals (Peake 1993; Roy 2016), which reproduce inequalities. Urban inequalities are directly related to vulnerability to risks and differentiated impacts during crises. For example, climate change often impacts the urban poor more severely, especially those lacking access to housing and other basic infrastructures (Hardoy and Pandiella 2009). Compound urban crises elevate these threats as vulnerable groups are exposed to multiple threats at once.

\section{Unbounding}

The CAS literature highlights emergence as a key property of complex adaptive systems (Holland 1998). Emergence explains how at the scale of a system, the interplay of agents shapes a hidden but recognisable regularity in the behaviour of the whole system. System-level properties, characteristics, and patterns emerge from interactions between individual elements, which generate qualitatively different characteristics (Railsback 2001). This means that the behaviour of a system as a whole cannot be observed in, or reduced to, its parts (Mingers 2014). When considering compound urban crises, emergence highlights how the interaction between different forms of disruption creates entirely new and unpredictable phenomena. Interaction between different forms of shock (e.g. in terms of patterns of impact, persistence over time, or cycles of intensity) is set against the existing complexity of the city and diverse dynamics of disruption (including interactions across temporal, spatial, and sectoral scales). Compound urban crises are interconnected between human and natural systems, across sectors and traditional governance silos, confounding the prediction of events and outcome of responses.

CUS highlights that uncertainty is an inherent quality of contemporary urbanism, meaning that it is not necessarily a problem to solve or a disorder to correct (Zeiderman et al. 2017). The scholarship also recognises the constantly shifting framing and social construction of crises. For example, while climate change once was framed as an environmental issue that could be tackled through singlesector interventions, it has become understood as a manifestation of modernity and a fundamental part of social life itself (Bulkeley 2021). As a result, addressing climate change requires interventions within a growing number of sectors and reflection on everyday social practices. Similarly, the concept of resilience has expanded from a narrow focus on recovery from climate shocks to encompass the multiple political-economic structures that maintain

\section{BOX 2 EXAMPLE OF UNEVENNESS-COVID-19 AND RACISM}

An example of unevenness is the connection between the crises of COVID-19 pandemic and institutionalised racism. In the U.S., the Black Lives Matter protests were a response to police brutality and racial injustice. Yet, they also followed recognition among people of all races of the compounded racialised vulnerabilities associated with living in low-income urban areas and lacking access to protective amenities (Rosan and Heckert 2020). During COVID-19, these inequalities translated into higher vulnerability to the virus among African Americans (Abedi et al. 2020). In urban regions, measures to contain the spread of the virus exacerbated stigmatised and racialised groups' vulnerability to state violence. In France, for example, citizens of banlieues (suburban low-income housing states) protested against police brutality, arrests, and fines to enforce lockdown measures. 
inequalities and risk (Ziervogel et al. 2017). Given the diverse and unanticipated ways compound crises manifest, there is a political imperative to rethink the categories that structure urban governance. actions across scales (Chan et al. 2015). Beyond the task of quantifying and monitoring impacts, we raise the question of how to build transnational to local solidarity to address invisibility and challenge legitimised notions of expendability (de Sousa Santos 2015) associated with communi-

\section{BOX 3 EXAMPLE OF UNBOUNDING-THE SHIFTING PROBLEM FRAMING OF COVID-19}

An example of unbounding is the constantly shifting framing of the COVID-19 pandemic-initially as a health crisis and eventually as a social, economic, and environmental problem. There was initially a strong focus on the health consequences of the virus, pathways of contagion, and infection rates. However, over time it became clear that the pandemic connects to other policy areas. The climate crisis interacts with the pandemic through the confluence of climate hazards and virus outbreak (Phillips et al. 2020) and the reduction of GHG emissions through restrictions on economic activity (Le Quéré et al. 2020). Links are made with seemingly disparate issues, such as housing (AI-Dafar 2020), illustrating the inherently cross-cutting and evolving nature of COVID-19 as part of compound crises.

\section{A RESEARCH AGENDA FOR THE STUDY OF COMPOUND URBAN CRISES}

These three boundary concepts capture challenges that, to some degree, are present in singular urban crises. However, the compounding of shocks increases their complexity, unpredictability, and persistence, thereby increasing concerns about ensuring effective and just urban governance. Below, we reflect on implications for research on the governance of compound urban crises.

The concept of unsettlement underlines interconnections between global dynamics and the politics of urban precarity. A CAS perspective explains how interventions within a city may generate useful synergies or unintended outcomes in another sector, location, or time (Coetzee et al. 2016), while the CUS scholarship underlines that any new shock is situated in a landscape of inequality and exclusion. There are two main directions of examination required to understand such interconnections. First, how do politics and relations in the city shape vulnerabilities to network interactions? Do particular ownership structures, management strategies, material configurations, or patterns of access to services and infrastructures affect exposure to global disruptions? If this is the case, how can governance arrangements be rearranged to reduce such vulnerabilities, particularly in ways that protect the most disadvantaged? Second, what are the links between transnational politics and urban risk? Policy and best practice for urban management circulate through international networks, lending legitimacy to certain programmes of action (e.g. renewable energy policy). Yet, such actions create risks and burdens for populations elsewhere (e.g. through material extraction and waste disposal), as witnessed, for example, through the phenomenon of sacrifice zones (Zografos and Robbins 2020). Calls have been raised to coordinate environmental ties at the receiving end of risks.

The challenge of unevenness draws attention to the reproduction of vulnerabilities in urban regions under preexisting conditions of injustice. We identify two main directions of research required to unpack this challenge. First, there is a need to examine how existing urban governance systems promote unevenness, including through path dependencies built into decision-making processes and policy rationalities. In many metropolitan regions in the U.S., for instance, governance systems are designed to reinforce inclusion and exclusion and the fragmented governance system allows for regional inequity (Rosan 2016). Likewise, financial instruments capitalise on contingency, fluidity, and uncertainty in urban contexts and convert these conditions into value that is commodified and exchanged, thus shaping geographies of investment and exclusion across the city. Second, we need a greater understanding of the impacts of policy strategies designed to tackle compound crises, such as attempts to link pandemic recovery with environmental interventions through 'green recovery' packages. While the social justice implications of such initiatives are not yet known, it is clear that responses to urban disruption often exacerbate unevenness. For example, actions to reduce climate impacts in urban areas often reproduce capitalist logics and entrench crisisprone modes of development (Long and Rice 2020). Stateled action to reduce economic instability that is fixed in neoliberal policy serves to recreate rather than ameliorate economic shocks (Jones and Ward 2002). Infrastructure investments may also cement inequalities along the lines of racial oppression (Pulido 2017).

The concept of unbounding highlights the challenge of responding to crises of a constantly shifting and unpredictable character. We see two ways forward in research on this problem. The first relates to realising a commitment to 
knowledge pluralism, in recognition that there is no one way to understand compound urban crises. These phenomena cannot be reduced to matters of fact; they are better confronted as 'matters of concern' with contested boundaries between facts and values (Latour 2004). Rather than reaffirming a 'monolithic' idea of science, research should foster transdisciplinary knowledge co-production (Webb et al. 2018). This also requires rethinking who counts as a 'stakeholder', to ensure the inclusion of groups beyond the usual suspects. For instance, the technocratic design of climate policy reflects and privileges participation of dominant organisations, which reproduces social injustice (Malloy and Ashcraft 2020). In particular, everyday experiences need to be considered while examining the nature and implications of crises. For example, the Black Lives Matter movement has exposed how everyday violence is the norm for black communities, rather than the exception (Anderson 2017). Power relations define what counts as an urban crisis, often in terms of how crises threaten urban elites' privileges and demands for security. Second, as the boundaries of traditional sectors dissolve, further research is required to understand how policy strategies may tackle multiple interacting drivers of vulnerability. It is not clear, for example, what forms of intervention might address external causes of instability (e.g. global environmental change or international finance) and urban conditions that perpetuate inequality (e.g. capitalist modes of development, political exclusion, or racism). While this remains an open question, future research could seek to clarify the effectiveness of policy interventions that target equity, inclusion, and social wellbeing. This may be realised by addressing multiple conditions that cause vulnerability, for example, by creating access to healthcare, safe and affordable housing, financial security, legal status, or considering issues of recognition.

\section{CONCLUSIONS}

We live in an age of compound urban crises; this is already significantly affecting the everyday lives of urban residents and has major consequences for urban governance. A key challenge is to make practical headway on compound urban crises without being paralysed by complexity. This encourages and requires reflexivity about unintended consequences of interventions. Yet, it also draws attention to co-beneficial actions and simultaneous interventions in multiple areas. Understanding how social-ecological problems are intertwined may be a step towards breaking down policy silos and adopting holistic political responses in a changing global environment.
While multiple crises co-exist, certain crises are elevated in news stories and many everyday crises remain invisible. Multiple points of view regarding what constitutes the most pressing form of disruption always co-exist and power relations determine which crises are presented as most urgent. We can only genuinely learn about experiences of crises through dialogue with those most affected by threat and uncertainty. At the same time, the need to draw on multiple views and experiences arises in an environment of political and social polarisation. As debates move towards extremes, there is little ground for collective deliberation and problem-solving. Likewise, rifts within academia limit conversations across disciplinary divide. This paper represents a bridging effort, employing CAS and CUS scholarship to develop three boundary concepts as an entry point for interdisciplinary discussion. We also identified parallels beyond these literatures, such as constructivist perspectives on policy studies. For example, the notion of punctuated evolution (Hay 2006) resonates with ideas of non-linear change in CAS, while the framing of equity in policy studies (Stone 1988) provides additional perspectives on unevenness. The core feature of boundary concepts is their ability to embrace diverse understandings without requiring consensus, allowing scholars to overcome the conceptual barriers that hamper knowledge production. We do not advocate Frankensteinian frameworks collating non-compatible forms of knowledge into unwieldy theoretical apparatuses. Rather, we argue that boundary concepts can cultivate an appreciation of how insights from other fields enrich and extend those of our own.

As we carefully map out the conceptual domain of compound crises, communities already respond to their impacts everyday, discovering what works through the application of lay expertise and learning by doing. Extended case studies are particularly useful in gaining insights from practice, serving as the empirical 'holding ground' for the theoretical anchor that boundary concepts represent. The storm we hope to navigate is the compelling problem of compound urban crises. Together, these ideas represent an initial communicative space to explore ways forward in a turbulent era.

Acknowledgements We appreciate the support of the Earth System Governance network and their assistance in arranging the inaugural meeting of the ESG Urban Working Group at the 2020 Earth System Governance. The contributions of Linda Westman, James Patterson and Vanesa Castán Broto have been funded by the project Low Carbon Action in Ordinary Cities (LO-ACT), that has received funding from the European Research Council (ERC) under the European Union's Horizon 2020 research and innovation programme Grant Agreement No 804051 — LO-ACT — ERC-2018-STG (PI: Castán Broto). 
Open Access This article is licensed under a Creative Commons Attribution 4.0 International License, which permits use, sharing, adaptation, distribution and reproduction in any medium or format, as long as you give appropriate credit to the original author(s) and the source, provide a link to the Creative Commons licence, and indicate if changes were made. The images or other third party material in this article are included in the article's Creative Commons licence, unless indicated otherwise in a credit line to the material. If material is not included in the article's Creative Commons licence and your intended use is not permitted by statutory regulation or exceeds the permitted use, you will need to obtain permission directly from the copyright holder. To view a copy of this licence, visit http://creativecommons. org/licenses/by/4.0/.

\section{REFERENCES}

Abedi, V., O. Olulana, V. Avula, D. Chaudhary, A. Khan, S. Shahjouei, J. Li, and R. Zand. 2020. Racial, economic, and health inequality and COVID-19 infection in the United States. Journal of Racial and Ethnic Health Disparities 9: 1-11.

AI-Dafar, B. 2020. What will future housing be like after the COVID19-pandemic? San Francisco: English Language Institute.

Amin, S. 2010. Ending the crisis of capitalism or ending capitalism? Oxford: Fahamu/Pambazuka.

Anderson, B. 2017. Emergency futures: Exception, urgency, interval, hope. The Sociological Review 65: 463-477.

Anguelovski, I., J.J. Connolly, H. Pearsall, G. Shokry, M. Checker, J. Maantay, K. Gould, T. Lewis, et al. 2019. Opinion: Why green "climate gentrification" threatens poor and vulnerable populations. Proceedings of the National Academy of Sciences 116: 26139-26143.

Ansell, C., A. Boin, and A. Keller. 2010. Managing transboundary crises: Identifying the building blocks of an effective response system. Journal of Contingencies and Crisis Management 18: 195-207.

Bahadur, A., and T. Tanner. 2014. Transformational resilience thinking: Putting people, power and politics at the heart of urban climate resilience. Environment and Urbanization 26: 200-214.

Barnett, J., L.S. Evans, C. Gross, A.S. Kiem, R.T. Kingsford, J.P. Palutikof, C.M. Pickering, and S.G. Smithers. 2015. From barriers to limits to climate change adaptation: path dependency and the speed of change. Ecology and Society. https://doi.org/10. 5751/ES-07698-200305.

Berkes, F., and H. Ross. 2013. Community resilience: Toward an integrated approach. Society \& Natural Resources 26: 5-20.

Bhattacharyya, G. 2015. Crisis, austerity, and everyday life: Living in a time of diminishing expectations. Basingstoke/New York: Palgrave.

Boin, A. 2019. The transboundary crisis: Why we are unprepared and the road ahead. Journal of Contingencies and Crisis Management 27: 94-99.

Boin, A., M. Ekengren, and M. Rhinard. 2020. Hiding in plain sight: Conceptualizing the creeping crisis. In Risk, hazards \& crisis in public policy, ed. A. Boin, M. Ekengren, and M. Rhinard. Cham: Springer.

Boin, A., E. Stern, and B. Sundelius. 2016. The politics of crisis management: Public leadership under pressure. Cambridge: Cambridge University Press.

Borie, M., M. Pelling, G. Ziervogel, and K. Hyams. 2019. Mapping narratives of urban resilience in the global south. Global Environmental Change 54: 203-213.
Buchheim, L., C. Krolage, and S. Link. 2020. Sudden stop: When did firms anticipate the potential consequences of COVID-19? SSRN Electronic Journal. https://doi.org/10.2139/ssrn.3648797.

Bulkeley, H. 2021. Climate changed urban futures: environmental politics in the anthropocene city. Environmental Politics. https:// doi.org/10.1080/09644016.2021.1880713.

Bulkeley, H., G.A.S. Edwards, and S. Fuller. 2014. Contesting climate justice in the city: Examining politics and practice in urban climate change experiments. Global Environmental Change 25: 31-40.

Butler, P., 2020. Covid-driven recession likely to push $2 \mathrm{~m}$ UK families into poverty, The Guardian, Online.

Castán Broto, V., E. Robin, and A. While. 2020. Climate urbanism: Towards a critical research agenda. Cham: Palgrave MacMillan.

Chan, S., H. van Asselt, T. Hale, K.W. Abbott, M. Beisheim, M. Hoffmann, B. Guy, N. Höhne, et al. 2015. Reinvigorating international climate policy: A comprehensive framework for effective nonstate action. Global Policy 6: 466-473.

Chu, E., and K. Michael. 2019. Recognition in urban climate justice: Marginality and exclusion of migrants in Indian cities. Environment and Urbanization 31: 139-156.

Coetzee, C., D. Van Niekerk, and E. Raju. 2016. Disaster resilience and complex adaptive systems theory: Finding common grounds for risk reduction. Disaster Prevention and Management. 25: 196-211.

Cote, M., and A.J. Nightingale. 2012. Resilience thinking meets social theory: Situating social change in socio-ecological systems (SES) research. Progress in Human Geography 36: 475-489.

Dauvergne, P., and L. Shipton, forthcoming. Global environmental politics in a turbulent era. Cheltenham: Edward Elgar.

de Sousa Santos, B. 2015. Epistemologies of the South: Justice against epistemicide. Abington: Routledge.

Dolan, D.A., G.B. Soule, J. Greaney, and J. Morris. 2010. Warming up to climate action: A survey of GHG mitigation through building energy efficiency in city climate action plans. Carbon \& Climate Law Review. 4: 2-12.

European Parliament, 2016. Precarious Employment in Europe-Part 1: Patterns, trends and policy strategy. Directorate General for Internal Policies. Policy Department A: Economic and Scientific Policy, Brussels.

Farazmand, A. 2001. Handbook of crisis and emergency management. CRC Press.

Fastenrath, S., and L. Coenen. 2021. Future-proof cities through governance experiments? Insights from the Resilient Melbourne Strategy (RMS). Regional Studies 55: 138-149.

Folke, C., S.R. Carpenter, B. Walker, M. Scheffer, T. Chapin, and J. Rockström. 2010. Resilience thinking: integrating resilience, adaptability and transformability. Ecology and Society. https:// doi.org/10.5751/ES-03610-150420.

Friend, R., and M. Moench. 2013. What is the purpose of urban climate resilience? Implications for addressing poverty and vulnerability. Urban Climate 6: 98-113.

Gay, R., C. Moser, J. Perlman, A. Bayat, J. Beall, M. Aguirre, O. Crankshaw, and S. Parnell. 2013. Megacities: the politics of urban exclusion and violence in the global south. London: Zed Books Ltd.

Ghertner, D.A. 2015. Why gentrification theory fails in 'much of the world.' City 19: 552-563.

Graham, S., and S. Marvin. 2002. Splintering urbanism: Networked infrastructures, technological mobilities and the urban condition. Abington: Routledge.

Haase, A., N. Bedtke, C. Begg, E. Gawel, D. Rink, and M. Wolff. 2018. On the connection between urban sustainability transformations and multiple societal crises. In Urban transformations: 
sustainable urban development through resource efficiency, quality of life and resilience, ed. S. Kabisch, F. Koch, E. Gawel, A. Haase, S. Knapp, K. Krellenberg, J. Nivala, and A. Zehnsdorf, 61-76. Cham: Springer.

Hardoy, J., and G. Pandiella. 2009. Urban poverty and vulnerability to climate change in Latin America. Environment and Urbanization 21: 203-224.

Harvey, D. 2011. Roepke lecture in economic geography-crises, geographic disruptions and the uneven development of political responses. Economic Geography 87: 1-22.

Hay, C. 2006. Constructivist institutionalism. In The Oxford handbook of political institutions, ed. R.A.W. Rhodes, S. Binder, and B. Rockman. Oxford: Oxford University Press.

Holland, J.H. 1998. Emergence: From chaos to order. Cambridge, MA: Perseus.

ILO. 2018. Women and men in the informal economy: A statistical picture, 3rd ed. Geneva: International Labour Office.

Jones, M., and K. Ward. 2002. Excavating the logic of British urban policy: Neoliberalism as the "crisis of crisis-management." Antipode 34: 473-494.

Kaika, M. 2012. The economic crisis seen from the everyday: Europe's nouveau poor and the global affective implications of a 'local'debt crisis. City 16: 422-430.

Katz, M.B. 2010. The existential problem of urban studies. Dissent 57: $65-68$

Keil, R., and H. Ali. 2007. Governing the sick city: Urban governance in the age of emerging infectious disease. Antipode 39: 846-873.

Khirfan, L., and H. El-Shayeb. 2020. Urban climate resilience through socio-ecological planning: A case study in Charlottetown, Prince Edward Island. Journal of Urbanism: International Research on Placemaking and Urban Sustainability 13: 187-212.

Kim, S.J., and W. Bostwick. 2020. Social vulnerability and racial inequality in COVID-19 deaths in Chicago. Health Education \& Behavior 47: 509-513.

Lancione, M. 2019. The politics of embodied urban precarity: Roma people and the fight for housing in Bucharest, Romania. Geoforum 101: 182-191.

Lancione, M. 2020. Radical housing: On the politics of dwelling as difference. International Journal of Housing Policy 20: 273-289.

Lansing, J.S. 2003. Complex adaptive systems. Annual Review of Anthropology 32: 183-204.

Latour, B. 2004. Which protocol for the new collective experiments? Experimental Culture 32/33: 17-36.

Le Quéré, C., R.B. Jackson, M.W. Jones, A.J. Smith, S. Abernethy, R.M. Andrew, A.J. De-Gol, D.R. Willis, et al. 2020. Temporary reduction in daily global CO 2 emissions during the COVID-19 forced confinement. Nature Climate Change 10: 647-653.

Lebel, L., J.M. Anderies, B. Campbell, C. Folke, S. Hatfield-Dodds, T.P. Hughes, and J. Wilson. 2006. Governance and the capacity to manage resilience in regional social-ecological systems. Ecology and Society. https://doi.org/10.5751/ES-01606-110119.

Lees, L. 2012. The geography of gentrification: Thinking through comparative urbanism. Progress in Human Geography 36: $155-171$.

Levin, S.A. 1998. Ecosystems and the biosphere as complex adaptive systems. Ecosystems 1: 431-436.

Levin, S., T. Xepapadeas, A.-S. Crépin, J. Norberg, A. De Zeeuw, C. Folke, T. Hughes, K. Arrow, et al. 2013. Social-ecological systems as complex adaptive systems: Modeling and policy implications. Environment and Development Economics 18: $111-132$

Li, X., Y. Song, G. Wong, and J. Cui. 2020. Bat origin of a new human coronavirus: There and back again. Science China Life Sciences 63: 461-462.
Long, J. and Rice, J.L., 2020. Climate urbanism: crisis, capitalism, and intervention. Urban Geography: 1-7.

Malloy, J.T., and C.M. Ashcraft. 2020. A framework for implementing socially just climate adaptation. Climatic Change 160: 1-14.

Marmot, M. 2020. Health equity in England: The Marmot review 10 years on. BMJ. https://doi.org/10.1136/bmj.m693.

McFarlane, C. 2011. Assemblage and critical urbanism. City 15: 204-224.

Meadows, D.H. 2008. Thinking in systems: A primer. Vremont: Chelsea Green Publishing.

Meerow, S., P. Pajouhesh, and T.R. Miller. 2019. Social equity in urban resilience planning. Local Environment 24: 793-808.

Mingers, J. 2014. Systems thinking, critical realism and philosophy: A confluence of ideas. Abington: Routledge.

Mitroff, I.I., M.C. Alpaslan, and S.E. Green. 2004. Crises as illstructured messes. International Studies Review 6: 175-182.

Mollinga, P.P., 2008. The rational organisation of dissent: Boundary concepts, boundary objects and boundary settings in the interdisciplinary study of natural resources management, ZEF working paper series (University of Bonn), Bonn.

Molotch, H., and J. Logan. 1984. Tensions in the growth machine: Overcoming resistance to value-free development. Social Problems 31: 483-499.

Muggah, R., and K. Savage. 2012. Urban violence and humanitarian action: Engaging the fragile city. The Journal of Humanitarian Assistance 19: 2012.

Muñoz-Erickson, T.A., S. Meerow, R. Hobbins, E. Cook, D.M. Iwaniec, M. Berbés-Blázquez, N.B. Grimm, A. Barnett, et al. 2021. Beyond bouncing back? Comparing and contesting urban resilience frames in US and Latin American contexts. Landscape and Urban Planning 214: 104173.

Nel, D., C. du Plessis, and K. Landman. 2018. Planning for dynamic cities: Introducing a framework to understand urban change from a complex adaptive systems approach. International Planning Studies 23: 250-263.

Nielsen, A.B., and M. Papin. 2021. The Hybrid Governance of Transnational Municipal Networks: Lessons from 100 Resilient Cities. Environment and Planning c: Politics and Space 39: 667-685.

Njoh, A.J. 2008. Colonial philosophies, urban space, and racial segregation in British and French colonial Africa. Journal of Black Studies 38: 579-599.

Olsson, L., A. Jerneck, H. Thoren, J. Persson, and D. O'Byrne. 2015. Why resilience is unappealing to social science: Theoretical and empirical investigations of the scientific use of resilience. Science advances 1: e1400217.

Olsson, P., C. Folke, and F. Berkes. 2004. Adaptive comanagement for building resilience in social-ecological systems. Environmental Management 34: 75-90.

Oppenheimer, M., M. Campos, R. Warren, J. Birkmann, G. Luber, B. O’Neill, K. Takahashi, M. Brklacich, et al. 2014. Emergent risks and key vulnerabilities, climate change 2014 impacts, adaptation and vulnerability: Part A: global and sectoral aspects, 1039-1100. Cambridge: Cambridge University Press.

Orleans Reed, S., R. Friend, V.C. Toan, P. Thinphanga, R. Sutarto, and D. Singh. 2013. "Shared learning" for building urban climate resilience-Experiences from Asian cities. Environment and Urbanization 25: 393-412.

Orr, C. 2020. The paradox of growth and the promise of unsettled times: Canadian politics of the economy and the environment 1867-2017. Montreal: McGill University.

Orsini, A., P. Le Prestre, P.M. Haas, M. Brosig, P. Pattberg, O. Widerberg, L. Gomez-Mera, J.-F. Morin, et al. 2020. Complex systems and international governance. International Studies Review 22: 1008-1038. 
Patterson, J., C. Wyborn, L. Westman, M.C. Brisbois, M. Milkoreit, and D. Jayaram. 2021. The political effects of emergency frames in sustainability. Nature Sustainability 1-10: 841-850.

Peake, L. 1993. 'Race'and sexuality: Challenging the patriarchal structuring of urban social space. Environment and Planning $d$ : Society and Space 11: 415-432.

Pearson, C.M., and I.I. Mitroff. 1993. From crisis prone to crisis prepared: A framework for crisis management. Academy of Management Perspectives 7: 48-59.

Phillips, C.A., A. Caldas, R. Cleetus, K.A. Dahl, J. Declet-Barreto, R. Licker, L.D. Merner, J.P. Ortiz-Partida, et al. 2020. Compound climate risks in the COVID-19 pandemic. Nature Climate Change 10: 586-588.

Picker, G. 2017. Racial cities: Governance and the segregation of Romani people in urban Europe. London: Taylor \& Francis.

Preiser, R., R. Biggs, A. De Vos, and C. Folke. 2018. Socialecological systems as complex adaptive systems. Ecology and Society. https://doi.org/10.5751/ES-10558-230446.

Pulido, L. 2017. Geographies of race and ethnicity II: Environmental racism, racial capitalism and state-sanctioned violence. Progress in Human Geography 41: 524-533.

Quarantelli, E.L., A. Boin, and P. Lagadec. 2018. Studying future disasters and crises: A heuristic approach, Handbook of disaster research, 61-83. New York: Springer.

Railsback, S.F. 2001. Concepts from complex adaptive systems as a framework for individual-based modelling. Ecological Modelling 139: 47-62.

Revi, A., D.E. Satterthwaite, F. Aragón-Durand, J. Corfee-Morlot, R.B.R. Kiunsi, M. Pelling, D.C. Roberts, and W. Solecki. 2014. Urban areas. Cambridge: IPCC.

Rivero-Villar, A. 2021. Longitudinal resilience building in self-help settlements: Achieving transformations to unlock adaptations. Geoforum 122: 152-163.

Robin, E., C. Chazal, M. Acuto, and R. Carrero. 2019. (Un) learning the city through crisis: Lessons from Cape Town. Oxford Review of Education 45: 242-257.

Rosan, C. and M. Heckert, 2020. Can an equity index promoting an environmentally 'Just' city help us beat pandemics, address iInjustice, and prepare us for climate change? COVID-19 Research.

Rosan, C.D. 2016. Governing the fragmented metropolis: Planning for regional sustainability. Philadelphia: University of Pennsylvania Press.

Roux-Dufort, C. 2009. The devil lies in details! How crises build up within organizations. Journal of Contingencies and Crisis Management 17: 4-11.

Roy, A. 2016. Who's afraid of postcolonial theory? International Journal of Urban and Regional Research 40: 200-209.

Ruiz-Campillo, X., V. Castán Broto, and L. Westman. 2021. Motivations and intended outcomes in local governments' declarations of climate emergency. Politics and Governance 9: $17-28$.

Schilling, H., T. Blokland, and A. Simone. 2019. Working precarity: Urban youth tactics to make livelihoods in instable conditions in Abidjan, Athens. Berlin and Jakarta. the Sociological Review 67: $1333-1349$.

Sehnbruch, K., and S. DonosoKnaudt. 2020. Social protests in Chile: inequalities and other inconvenient truths about Latin America's poster child. Global Labour Journal. https://doi.org/10.15173/ glj.v11i1.4217.

Serre, D., and C. Heinzlef. 2018. Assessing and mapping urban resilience to floods with respect to cascading effects through critical infrastructure networks. International Journal of Disaster Risk Reduction 30: 235-243.
Shi, L., E. Chu, I. Anguelovski, A. Aylett, J. Debats, K. Goh, T. Schenk, K.C. Seto, et al. 2016. Roadmap towards justice in urban climate adaptation research. Nature Climate Change 6: 131-137.

Simone, A. 2018. Improvised lives: Rhythms of endurance in an urban south. New York: Wile.

Sohrabi, C., Z. Alsafi, N. O’Neill, M. Khan, A. Kerwan, A. Al-Jabir, C. Iosifidis, and R. Agha. 2020. World Health Organization declares global emergency: A review of the 2019 novel coronavirus (COVID-19). International Journal of Surgery 76: $71-76$.

Stone, D.A. 1988. Policy paradox and political reason. Northbrook: Scott Foresman \& Company, Glenview.

't Hart, P. 1993. Symbols, rituals and power: The lost dimensions of crisis management. Journal of Contingencies and Crisis Management 1: 36-50.

't Hart, P., L. Heyse, and A. Boin. 2001. New trends in crisis management practice and crisis management research: Setting the agenda. Journal of Contingencies and Crisis Management 9: $181-188$.

Turner, J.R., and R.M. Baker. 2019. Complexity theory: An overview with potential applications for the social sciences. Systems 7: 4.

Van der Heijden, J. 2017. Innovations in urban climate governance: Voluntary programs for low carbon buildings and cities. Cambridge: Cambridge University Press.

Vilenica, A., E. McElroy, M. Ferreri, M. Fernández Arrigoitia, M. García-Lamarca, and M. Lancione. 2020. Covid-19 and housing struggles: The (re) makings of austerity, disaster capitalism, and the no return to normal. Radical Housing Journal 2: 9-28.

Wahl, T., S. Jain, J. Bender, S.D. Meyers, and M.E. Luther. 2015. Increasing risk of compound flooding from storm surge and rainfall for major US cities. Nature Climate Change 5: 1093.

Walker, B., S. Carpenter, C. Folke, L. Gunderson, G. Peterson, M. Scheffer, M. Schoon, and F. Westley. 2020. Navigating the chaos of an unfolding global cycle. Ecology and Society 25: 23.

Walker, B., C.S. Holling, S.R. Carpenter, and A. Kinzig. 2004. Resilience, adaptability and transformability in social-ecological systems. Ecology and Society. https://doi.org/10.5751/ES-00650090205.

Webb, R., X. Bai, M.S. Smith, R. Costanza, D. Griggs, M. Moglia, M. Neuman, P. Newman, et al. 2018. Sustainable urban systems: Co-design and framing for transformation. Ambio 47: 57-77. https://doi.org/10.1007/s13280-017-0934-6

Weinstein, L., A. Rumbach, and S. Sinha. 2019. Resilient growth: Fantasy plans and unplanned developments in india's floodprone coastal cities. International Journal of Urban and Regional Research 43: 273-291.

Westman, L., and V. Castán Broto, 2021, forthcoming. Urban transformations to keep all the same: The power of ivy discourses. Antipode.

Wu, F., S. He, and C. Webster. 2010. Path dependency and the neighbourhood effect: Urban poverty in impoverished neighbourhoods in Chinese cities. Environment and Planning A 42: 134-152.

Zeiderman, A., S. Kaker, J. Silver, A. Wood, and K. Ramakrishnan. 2017. Urban uncertainty: Governing cities in turbulent times. London: LSE Cities.

Ziervogel, G., M. Pelling, A. Cartwright, E. Chu, T. Deshpande, L. Harris, K. Hyams, J. Kaunda, et al. 2017. Inserting rights and justice into urban resilience: A focus on everyday risk. Environment and Urbanization 29: 123-138.

Zografos, C., and P. Robbins. 2020. Green sacrifice zones, or why a green new deal cannot ignore the cost shifts of just transitions. One Earth 3: 543-546.

Zscheischler, J., S. Westra, B.J.J.M. Van Den Hurk, S.I. Seneviratne, P.J. Ward, A. Pitman, A. AghaKouchak, D.N. Bresch, et al. 
2018. Future climate risk from compound events. Nature Climate Change 8: 469.

Publisher's Note Springer Nature remains neutral with regard to jurisdictional claims in published maps and institutional affiliations.

\section{AUTHOR BIOGRAPHIES}

Linda Westman $(\square)$ is a Research Associate at the Urban Institute of the University of Sheffield. Her research revolves around environmental politics, urban climate governance, transformations, and justice.

Address: Urban Institute, University of Sheffield, 419 Portobello, Sheffield S14DP, UK.

e-mail: linda.westman@sheffield.ac.uk; 1.westman@sheffield.ac.uk

James Patterson is an Assistant Professor at the Copernicus Institute of Sustainable Development at Utrecht University, The Netherlands. His research focuses on the institutional and policy dynamics of climate action, at urban, subnational, and national scales.

Address: Copernicus Institute of Sustainable Development, Faculty of Geosciences, Vening Meineszgebouw A, Princetonlaan 8A, 3585CB Utrecht, The Netherlands.

e-mail: j.j.patterson@uu.nl

Rachel Macrorie is a Postdoctoral Researcher at the Transforming Cities Hub at the University of Utrecht, and an Associate Researcher at the Urban Institute, University of Sheffield. Her research focuses on the politics and governance of urban infrastructures, innovation, and everyday practices for ecological sustainability and social justice.

Address: Transforming Cities Hub, Human Geography and Spatial Planning Department, University of Utrecht, Princetonlaan 8a, 3584 CB Utrecht, The Netherlands.

e-mail: r.m.macrorie@uu.nl

Christopher J. Orr is a Postdoctoral Fellow in the Sustainability Policy Research on Urban Transformations Lab at the University of Waterloo. His research and policy work uses systems thinking and environmental sociology to understand governance systems and address complex environmental policy problems. He recently coedited Liberty and the Ecological Crisis: Freedom on a Finite Planet (Routledge).

Address: University of Waterloo, 200 University Avenue, Waterloo, ON N2L 3G1, Canada.

e-mail: christopher.orr@mail.mcgill.ca

Catherine M. Ashcraft is an Assistant Professor in the Department of Natural Resources and the Environment and a faculty fellow at the Carsey Schothol of Public Policy at the University of New Hampshire. Her research focuses on environmental policy and planning and how institutions are negotiated and designed to foster justice and respond to change.

Address: Department of Natural Resources \& the Environment, University of New Hampshire, 134 James Hall, 56 College Road, Durham, NH 03824, USA.

e-mail: catherine.ashcraft@unh.edu

Vanesa Castán Broto is Professor of Climate Urbanism at the University of Sheffield. Her last books are Climate Urbanism (2020, Palgrave) and Inclusive Urban Development in the Global South (2021, Routledge).

Address: Urban Institute, University of Sheffield, 419 Portobello, Sheffield S14DP, UK.

e-mail: v.castanbroto@sheffield.ac.uk
Dana Dolan is a Policy Fellow with the Schar School of Policy and Government at George Mason University. Her research on long-term governance centres on public policy processes, decision making, and the agency of actors in the policy process.

Address: Schar School of Policy and Government at, George Mason University, 3351 Fairfax Drive, Arlington, VA 22201, USA.

e-mail: ddolan1@gmu.edu

Mukesh Gupta is an Assistant Professor at the Department of Environmental Sciences of the Asian University for Women. His research interests focus on energy and natural resource policy analysis with specialised experience in climate change \& energy for development, and analysis of multiple impacts of climate actions.

Address: Department of Environmental Sciences, Asian University for Women, 20/A M. M. Ali Road, Chattogram 4000, Bangladesh. e-mail: mukesh.gupta@auw.edu.bd

Jeroen van der Heijden is a Professor at the School of Government at Victoria University of Wellington. His research is located at the intersection of public governance and regulation, with specific interests in urban climate governance.

Address: Wellington School of Business and Government of Victoria University of Wellington, Rutherford House, Pipitea Campus, Wellington 6011, New Zealand.

e-mail: jeroen.vanderheijden@vuw.ac.nz

Thomas Hickmann is an Associate Senior Lecturer at the Department of Political Science at Lund University. His research is mainly concerned with multi-level dynamics in global climate and sustainability governance.

Address: Faculty of Social Sciences, Department of Political Science, Lund University, Allhelgona kyrkogata 14, 22100 Lund, Sweden.

e-mail: thomas.hickmann@svet.lu.se

Robert Hobbins is a Postdoctoral Research Associate at the Urban Studies Institute at Georgia State University. His research focuses on urban resilience, sustainability transformations, knowledge system innovation, and sustainability education.

Address: Urban Studies Institute, Georgia State University, 55 Park Place NE, Atlanta, GA 30303, USA.

e-mail: rhobbins@gsu.edu

Marielle Papin is a Postdoctoral Fellow at McGill University Department of Geography. Her research revolves around global environmental politics, and more specifically global urban climate governance and transnational networks and actors.

Address: McGill University, 805 Rue Sherbrooke Ouest, Montréal, QC H3A 0B9, Canada.

e-mail: marielle.papin@mail.mcgill.ca

Enora Robin is a Leverhulme Early Career Fellow at the Urban Institute of the University of Sheffield. Her research focuses on urban climate action, renewable energy transitions, financing, and urban justice.

Address: Urban Institute, University of Sheffield, 419 Portobello, Sheffield S14DP, UK.

e-mail: e.robin@sheffield.ac.uk

Christina Rosan is an Associate Professor at the Department of Geography and Urban Studies at Temple University. Her research is focussed on the question of how we make cities more sustainable and just.

Address: Department of Geography and Urban Studies at Temple University, 320 Gladfelter Hall, 1115 Polett Walk, Philadelphia, PA, USA.

e-mail: cdrosan@temple.edu 
Jonas Torrens is an Assistant Professor at the Department of Industrial Engineering \& Innovation Sciences at the Eindhoven University of Technology, and former postdoc at the Copernicus Institute of Sustainable Development. His research focuses on how to enable sustainability transitions and transformations in just and democratic ways.

Address: Dep of Industrial Engineering and Innovation Sciences, Eindhoven University of Technology, PO Box 513, 5600 MB Eindhoven, The Netherlands.

e-mail: j.colenladeiatorrens@uu.nl
Robert Webb is an Honorary Associate Professor at the Australian National University. His research interests include sustainable urban development, responses to climate change, and cross-sector and crossscale governance and transformations

Address: Institute for Climate, Energy and Disaster Solutions and Fenner School of Environment and Society, Australian National University, Canberra ACT 2600, Australia.

e-mail: bob.webb@anu.edu.au 